\title{
Oksana Strutynska
}

National Pedagogical Dragomanov University, Kyiv, Ukraine

http://orcid.org/0000-0003-3555-070X

\section{Mariia Umryk}

National Pedagogical Dragomanov University, Kyiv, Ukraine

https://orcid.org/0000-0002-0396-0045

\section{Distance, Online and Blended Learning as Main Educational Trends During Pandemic 2020 Conditions}

\begin{abstract}
Distance learning and self-education have been an actual trend for many years but during the pandemic, it became critically relevant and important. The closure of schools and higher education institutions around the world had a negative impact on the educational sector in many countries in general and has affected almost every student and educator. This paper examines Ukrainian educators' level of knowledge and skills in using modern distance learning tools and trends and the way of improving the teaching-learning process during the conditions of the 2020 pandemic. The authors present their review of educational trends under the conditions of distance, online and blended learning. They also examine the Ukrainian educators' level of knowledge and skills in using modern distance learning tools and trends. For this purpose, the authors have elaborated and implemented a local survey for a Ukrainian university teaching staff (target group) who need to use distance learning tools in their research and professional activity during the quarantine. The authors also present the ways of improving the learning process via distance learning tools.

K e y w o r d s: distance learning tools, distance learning trends, COVID-19, digital transformation, learning tools, educational trends
\end{abstract}


The trend towards distance learning and self-education has been unchanged for many years but during the pandemic, it became critically relevant and important. The closure of schools and higher education institutions around the world has had a negative impact on the educational sector in many countries in general and has affected almost every student and educator.

The statistics (on the official UNESCO portal) indicate that more than $60 \%$ of pupils and students worldwide have faced the problem of full or partial closure of schools (Education: From disruption to recovery. UNESCO, 2020). Data as of August 3, 2020 show that 1,058,547,236 pupils and students around the world have suffered from full or partial closure of educational institutions. This is $60.5 \%$ of the total number of pupils and students in the world. It is also stated that as of August 3, 2020, 105 countries have closed educational institutions (Education: From disruption to recovery. UNESCO, 2020).

Therefore, many schools and universities use every opportunity to keep the learning process going. For this purpose, all educational technologies for distance learning are widely used: the Internet, television, mobile communication, etc. Educators of all countries are faced with the issue of implementation of the distance learning process without losing the quality of such training compared to the classical pre-quarantine training. Thus, considering the 2020 pandemic, distance learning tools are very important tools of modern education at all levels.

Problem of Research. This paper examines the level of knowledge and skills of selected Ukrainian educators in using modern distance learning tools and trends and the way of improving the teaching-learning process during the conditions of the 2020 pandemic.

Research Focus. Taking into account the rapid development of digital technologies, the authors believe that the efficiency of education in general will be increased by improving the teaching-learning process during the 2020 pandemic conditions and in the future, after the pandemic conditions have loosened.

\section{Methodology of Research}

The goal of the research is to address the following issues:

- analysis of the modern trends in education;

- analysis of the readiness level of Ukrainian educators (from target group) in the use of distance learning tools, according to the conducted survey;

- consideration of the ways of improving the teaching-learning process via distance tools and during the 2020 pandemic conditions. 
Distance, Online and Blended Learning as Main Educational Trends...

Research methods. The authors have used the following research methods and tools for the investigation (2020):

- survey;

- interview with selected Ukrainian educators;

- documents and content analysis;

- analysis of research papers.

194 Ukrainian educators have taken part in the present research. The Ukrainian educators from the target group (university teaching staff from the Dragomanov National Pedagogical University, Kyiv, Ukraine), have been involved in this process.

The survey was created to collect data on the readiness level of the university teachers to use distance learning tools.

\section{The Results of the Research}

\section{Educational Trends Under the Conditions of Distance, Online and Blended Learning}

Huawei presented to the world the latest Global Industry Vision (GIV) report, which outlined the impact of technology in the coming years and identified various technological trends (techno-trends) of the future until 2025 (Huawei Predicts 10 Megatrends for 2025), (Economic Strategy of Ukraine 2030. Ukrainian Institute of the Future), (Morze, Kucherovska, \& Smyrnova-Trybulska, 2020). They include:

- the use of bots (penetration of bot technology into social life is expected to be $14 \%)$

- virtual and augmented reality technologies (the percentage of industries that use VR/AR will increase to $10 \%$ );

- no-search service (the trend of equipping daily-used devices with special sensors which allows the device to anticipate human needs and meet them without human influence. GIV predicts that $90 \%$ of owners of smart devices will use intelligent personal assistants);

- robotization;

- enhanced creativity (access to cloud services will reduce barriers to scientific experimentation, innovation and art, opening horizons for creativity. GIV predicts that $97 \%$ of large companies will use such technologies);

- communication without borders;

- cloud technologies expansion (up to $85 \%$ of applications are projected to be cloud-based).

IJREL.2021.7.1.02 p. 3/25 
Under such conditions, society and education should evolve and focus on the future, train professionals who will turn innovations into inventions, and, consequently, produce a transformation within the educational environment, which, in turn, will provide comprehensive competency and modern approach to education (Morze, Kucherovska, \& Smyrnova-Trybulska, 2020, p. 75).

Existing research (Sánchez Begines, et al., 2017), (NMC Horizon Report Preview, 2018), (Morze, Vember, \& Hladun, 2019), (Morze, Kucherovska, \& Smyrnova-Trybulska, 2020), (Hrynevych, 2020) examines current educational trends and their impact on the formation of educational policy in the field of the digitalization of educational institutions. Based on their analysis, the authors identify the following educational trends:

- lifelong learning;

- distance learning, online learning;

- blended learning;

- informal learning (also MOOCs);

- STEAM education;

- gamification;

- multidisciplinary environments;

- mobile technology in education;

- cloud technology in education;

- VR, AR, MR;

- 3D printing and robotics in education;

- coding for children/young adults.

Thus, an important issue for quality education under the quarantine conditions is proficiency in modern ICT in education, which primarily includes distance learning, online and blended learning technologies.

Distance, online and blended learning are interrelated. Blended learning uses distance and online learning technologies. Distance learning uses online learning, but it can also be done in an asynchronous mode.

The concept of blended learning appeared in the 1990s, as opposed to online learning, Blended learning was implemented in some forms in the university system of North Carolina in the mid-1990s as a pilot project. In general, people started to study and implement it only after the beginning of the 2000s. The term «blended learning» has different definitions in the literature and means a combination of online learning, traditional (full-time) and independent learning and in different proportions. Other names include: «hybrid learning» and «flexible learning».

Blended learning is not the same as distance (or online) learning. Online learning does not involve personal communication between students in the classroom (or between students and teachers). It is also its main advantage and dis- 
Distance, Online and Blended Learning as Main Educational Trends...

advantage compared to blended learning, as students who study online do not have the opportunity to communicate personally and develop teamwork skills (Blended learning: essence and advantages in the modern world ,2019). Blended learning means group learning, self-study that can be done both in classrooms and online.

In 2007, experts from the Sloan Consortium classified several models of the learning process, depending on the use of distance learning technologies (Rashevska, 2010), (Allen \& Seaman, 2011), (Buhaichuk, 2016):

- traditional / classroom learning (0\%);

- full-time / face-to-face learning, enhanced by distance technologies (the use of distance technologies up to $30 \%$ );

- blended learning (the use of distance technologies up to 80\%);

- online learning (the use of distance learning technologies - more than $80 \%$ ).

The classification of the learning process models based on the use of distance learning technologies is presented in Table 1 (Rashevska, 2010), (Allen \& Seaman, 2011), (Buhaichuk, 2016):

Table 1

Classification of the learning process models based on the use of distance learning technologies (according to Sloan Consortium's findings)

\begin{tabular}{|c|c|c|}
\hline $\begin{array}{l}\text { Percentage of use } \\
\text { of distance learning } \\
\text { technologies }\end{array}$ & $\begin{array}{l}\text { Model of learning } \\
\text { process }\end{array}$ & Brief description \\
\hline $0 \%$ & $\begin{array}{l}\text { Traditional (classroom) } \\
\text { learning }\end{array}$ & $\begin{array}{l}\text { Information is delivered orally or in writ- } \\
\text { ing (digital technologies are not used), } \\
\text { asynchronous interaction is not carried } \\
\text { out }\end{array}$ \\
\hline $1-29 \%$ & $\begin{array}{l}\text { Use of distance } \\
\text { learning technologies }\end{array}$ & $\begin{array}{l}\text { Network technologies are used, but } \\
\text { mostly for the delivery of educational } \\
\text { material and organizational issues } \\
\text { within the traditional learning of a spe- } \\
\text { cific discipline }\end{array}$ \\
\hline $30-79 \%$ & Blended learning & $\begin{array}{l}\text { Network technologies are used not only } \\
\text { for the delivery of educational material, } \\
\text { but also for task performance, coopera- } \\
\text { tion and other educational interactions. } \\
\text { Face-to-face meetings are kept to a } \\
\text { minimum }\end{array}$ \\
\hline $80+\%$ & Online learning & $\begin{array}{l}\text { All educational activities and delivery } \\
\text { of educational material are carried out } \\
\text { using network technologies. No face-to- } \\
\text { face meetings are scheduled }\end{array}$ \\
\hline
\end{tabular}

S o u r c e: Own work based on Buhachuk (2016)

IJREL.2021.7.1.02 p. 5/25 
The Clayton Christensen Institute (USA), which has been studying blended learning for many years, notes that it is a form of learning within which a student receives a formal educational program (Clayton Christensen Institute for Disruptive Innovation. Blended Learning). The student:

1. Partially learns online using materials located on the Internet (with elements of self-control, at an individual pace, anywhere, at a convenient time, etc.).

2. Partially learns in the classroom under the supervision of a teacher (students physically attend the institution for face-to-face classes; at the same time, they should complete at least part of the curriculum not at home but at school, according to the schedule).

3. Gains a comprehensive (complex) learning experience (this is due to a combination of full-time and online learning).

\section{Examination of Ukrainian Educators' Knowledge of Current Trends in Virtual Education and Their Skills in the Use of Modern Distance Learn- ing Tools}

Areas of digital technology are the basis for digital transformations in Ukraine. The analysis of these trends makes it possible to predict the development of specific economic, technological, and even social phenomena in the future (Project "Digital agenda of Ukraine 2020", 2016, p. 12).

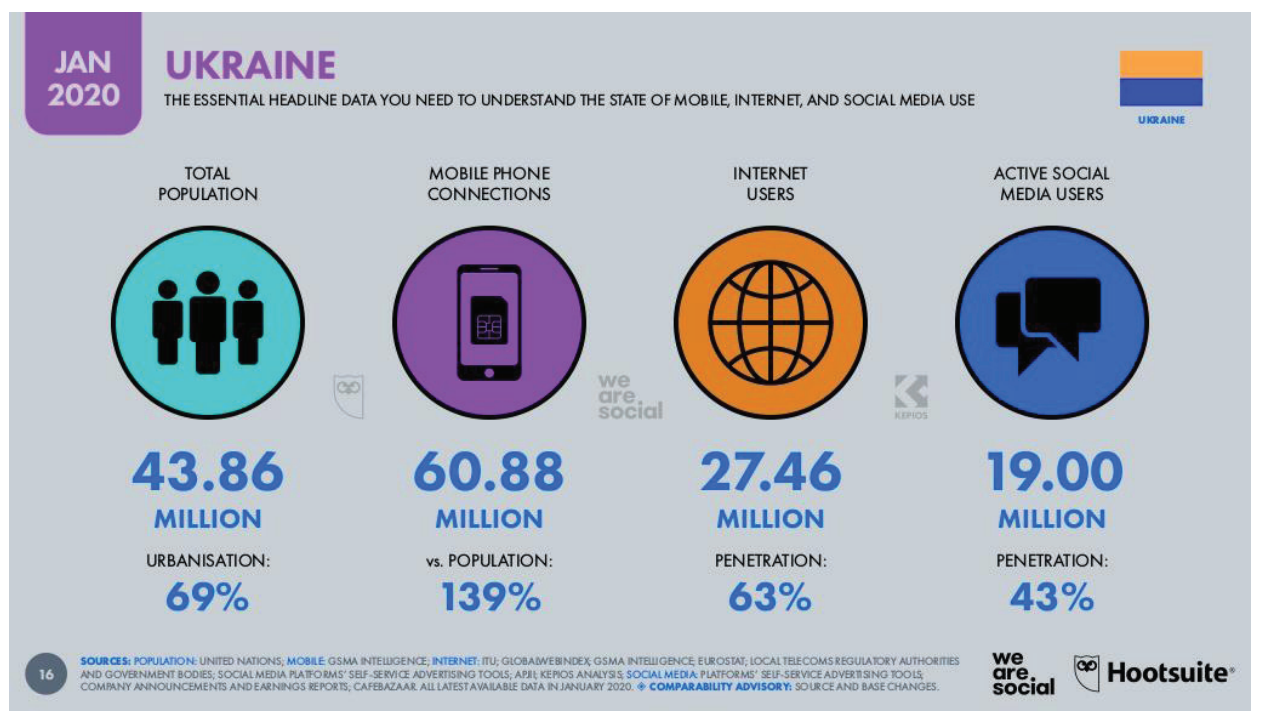

Figure 1. Statistics on the use of digital technologies in Ukraine.

S o u r c e: Kemp S. (2020) «Digital 2020 Ukraine» Hootsuite \& We Are Social, retrieved from https:// datareportal.com/reports/digital-2020-ukraine (accessed on 27.08.2020) 
Distance, Online and Blended Learning as Main Educational Trends...

The statistical data of the Data reportal (supported by the agency We Are Social and the social media management platform HootSuite) also acknowledges that digital technology is now an integral part of human life. These trends are also present in Ukraine. At the beginning of 2020, it has been determined that more than half of the population in Ukraine are Internet users (63\%). $43 \%$ are already active users of social networks (Hootsuite \& We Are Social, 2020). It is noted that Ukrainians use almost 61 million mobile devices; in general, one person has more than one mobile device (Fig. 1).

The dynamics of changes in the use of digital technologies in Ukraine is presented in Fig. 2:

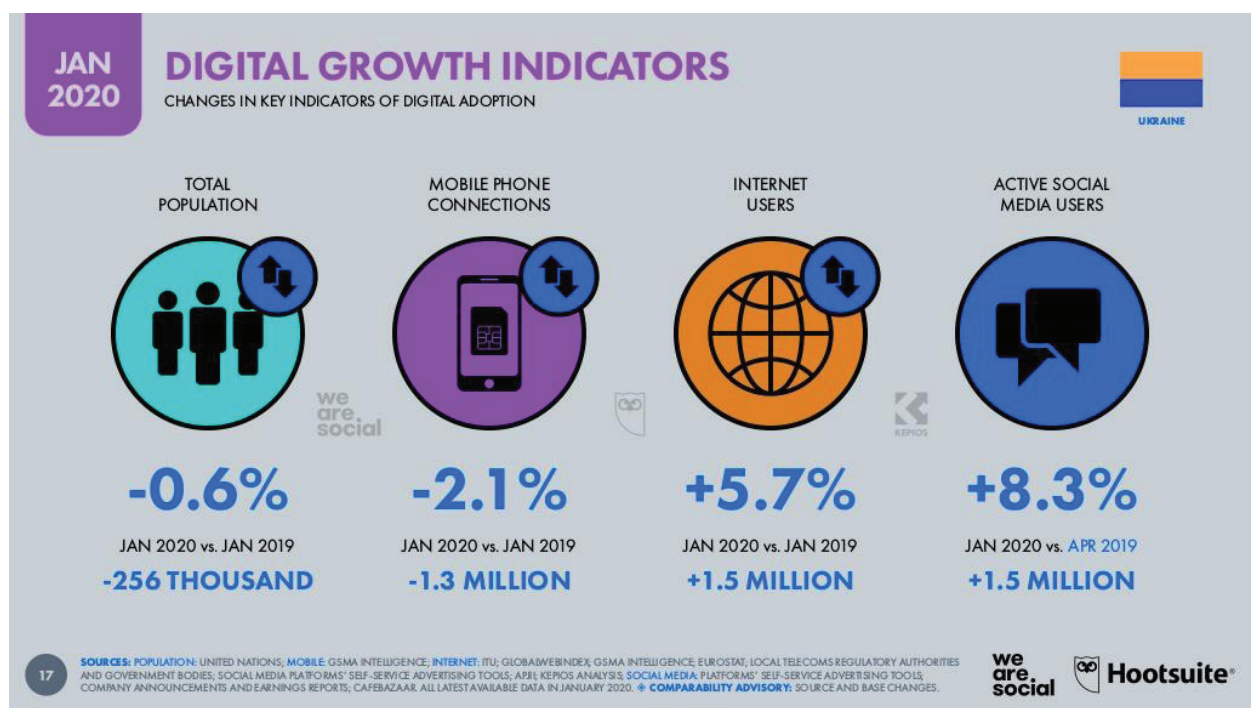

Figure 2. Dynamics of changes of the use of digital technologies in Ukraine.

S o u r c e: Kemp S. (2020) «Digital 2020 Ukraine,» Hootsuite \& We Are Social, retrieved from https:// datareportal.com/reports/digital-2020-ukraine (accessed on 27.08.2020)

As we can see from Fig. 2, the number of Ukrainian Internet users increased from January 2019 to January 2020 (by 5.7\% - about 1.5 million people). The number of active social media users had also increased (by $8.3 \%$ - about 1.5 million people).

This shows that digital technology is an integral part of human life. Digital transformation is becoming the basis of global economic development, which provides benefits to both consumers and businesses that adapt to the technological changes.

Among many other countries, Ukraine is also developing a digital transformation strategy aimed at supporting sustainable economic growth and increasing the 
productivity of the economy. In recent years, several important steps have been taken in this direction, namely the adoption of such documents as:

- EU4Digital initiative between the EU and the EU's Eastern Neighborhood (2016);

- project «Digital Agenda of Ukraine - 2020» (2016);

- The Concept for development of the digital economy and society for 2018-2020 in Ukraine (2018);

- Creation of the Ministry of Digital Transformation of Ukraine (2019).

Citizens are the key resource of the digital society. They are able to use digital technologies for their own needs effectively and productively (self-realization, work, study, and leisure), as well as to achieve common economic, social and civilian goals. In this regard, the development of digital skills and competencies of Ukrainians acquires special significance, which cannot be realized without the transformation of education.

The directions of the modernization of education largely depend on the needs of the labor market, which, recently, has been very dynamic. In the conditions of the rapid development of high technologies, higher education institutions, first of all pedagogical ones, need to make adjustments in various aspects of their activity, in particular, to update the content of their training.

The digital transformation of education opens wide prospects for improving the efficiency of the educational process, deepening the professionalism of educators. The requirements of teachers and lecturers are being constantly updated. New and more sophisticated sets of competencies are required to meet the rapid changes in the digital society. The rapid spread of digital devices, their diversity, and popularity among students leads to the need to develop the digital competence of educators (Strutynska \& Umryk, 2018), (Morze, Vember, \& Hladun, 2019).

The situation in the world, which has arisen due to the pandemic of 2020, is leading to fundamental changes in the educational systems of many countries, including Ukraine. Due to quarantine measures, blended and distance learning technologies come to the fore. Now, skills in the use of distance learning tools are necessary for all educators in Ukraine. So, it is important to examine the Ukrainian educators' level of knowledge and skills in using modern distance learning tools.

The present research is based on a target group that needs to use distance learning tools in their professional activity. This target group consisted of 194 Ukrainian university educators from the Dragomanov National Pedagogical University (Kyiv, Ukraine).

The online survey was elaborated in Ukrainian using Google Forms to collect responses concerning the Ukrainian educators' readiness level to use ICT in their professional activity, especially distance learning tools. We guaranteed participants that only anonymized data would be shared. 
Distance, Online and Blended Learning as Main Educational Trends...

The survey was open for a 3-month period between March and June 2020 (the time of the quarantine). It contained information about modern distance learning tools.

The survey included 26 questions divided into three groups:

- general information (about the educational role, discipline, age, sex, etc.);

- questions related to the educators' professional activities with the use of distance learning tools under the conditions of the quarantine;

- questions determining the general distance learning readiness of the university educators under the quarantine (problems, readiness for training, etc.).

The distribution of respondents by educational role is shown in Fig. 3.

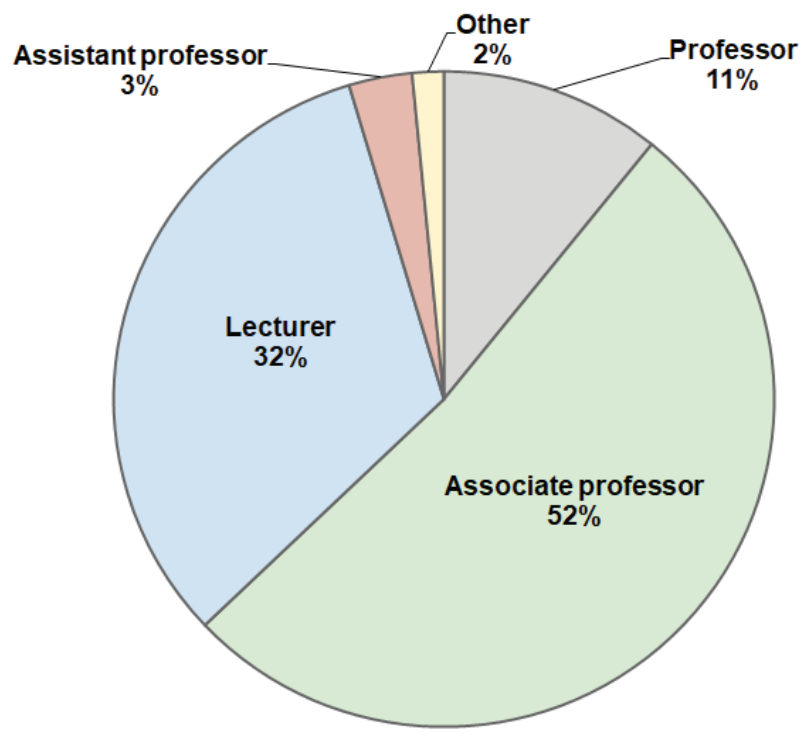

Figure 3. Distribution of respondents by educational role.

S ou r e: Own work

As we can see from Fig. 3, the largest group of respondents is associate professor (52\% of the participants - 101 people). The number of lecturers is 63 people (32\% of the participants) and the number of professors is 21 people (11\% of the respondents). The smallest group of participants is assistant professor (3\% of the participants -6 people). The «other" group includes moderators and department assistants who are not teachers. They are the support staff of the university.

It is drastically important to analyze and describe the readiness level of the educators from the Dragomanov National Pedagogical University (Kyiv, Ukraine) 
to use distance learning tools and online learning tools under the quarantine conditions. They are training and preparing the future teachers of the country. Their future professional activity depends on how effectively university teachers will teach their students - the future teachers - with the use of distance learning tools and online learning tools. Namely, the more effectively the university teachers will teach future teachers to use distance learning tools and online learning tools, the more effectively the latter will use them in teaching at school.

\subsection{The readiness level of the selected group of Ukrainian educators to use distance learning and online learning tools}

The data on the readiness level of the Ukrainian educators from the target group to use distance learning and online learning tools are presented in Tables $2-3$ and Fig. $4-5$ below.

Q1: Do you use distance learning activities during the quarantine?

All respondents answered «yes», but the next questions and answers will show the tools used.

Q2: What distance learning platforms do you use?

Survey responses on distance learning platforms' usage are shown in Table 2 (multiple answers are possible, which is why the total responses may be more than $100 \%)$ :

Table 2

Responses' distribution on distance learning platforms usage

\begin{tabular}{lc}
\hline \multicolumn{1}{c}{ Distance learning platforms } & Responses \\
\hline Google Classroom & $30.41 \%$ \\
Moodle & $68.56 \%$ \\
Microsoft Teams & $1.03 \%$ \\
Tebo & $0.52 \%$ \\
Schoology & $0.52 \%$ \\
Other tools & $4.64 \%$ \\
I don't use any platforms & $0.52 \%$ \\
\hline
\end{tabular}

S ou rce: Own work

As we can see from Table 2, almost all university educators have used distance learning platforms, especially Moodle (68.56\%) and Google Classroom (30.41\%). The Dragomanov National Pedagogical University has its own educational envi- 
Distance, Online and Blended Learning as Main Educational Trends...

ronment based on Moodle (moodle.npu.edu.ua). That is why the common answer to this question was «Moodle». In addition, educators have used Google Classroom because it is a freeware and friendly-interface distance-learning platform. Among the answers «Other tools», respondents sometimes wrote «e-mail», «Zoom», «Telegram», «Viber», «Skype», etc. It shows that educators do not know that these tools are not distance learning platforms.

Q3: What tools for video conferencing meeting do you use in your professional activity?

Survey responses on video conferencing meeting tools' usage are shown in Table 3 (multiple answers are possible, which is why the total responses may be more than $100 \%$ ):

Table 3

Distribution of responses on video conferencing meeting tools usage

\begin{tabular}{lc}
\hline \multicolumn{1}{c}{ Video conferencing meeting tools } & Responses \\
\hline Google Hangouts Meet & $11.34 \%$ \\
Zoom & $50 \%$ \\
Microsoft Teams & $2.06 \%$ \\
Skype & $53.09 \%$ \\
Viber & $6.19 \%$ \\
Telegram & $2.06 \%$ \\
YouTube Live & $8.76 \%$ \\
Other tools & $3.61 \%$ \\
I don't use any tools & $14.95 \%$ \\
\hline
\end{tabular}

S ource: Own work

Survey responses on video conferencing meeting tools' usage distributed by educational role are shown in Fig. 4 (multiple answers are possible, which is why the total responses may be more than $100 \%$ ).

As we can see from Fig. 4, the largest group of respondents $(53.09 \%)$ used Skype as a video conferencing meeting tool. The popularity of this tool can be explained by the fact that teachers have previously used it for personal communication. As for Zoom, it is used by half of the respondents (50\%), which can be explained by its simple interface and the availability of browser and free versions of this software. At the same time, about $15 \%$ of educators from the target group did not use any tools. 


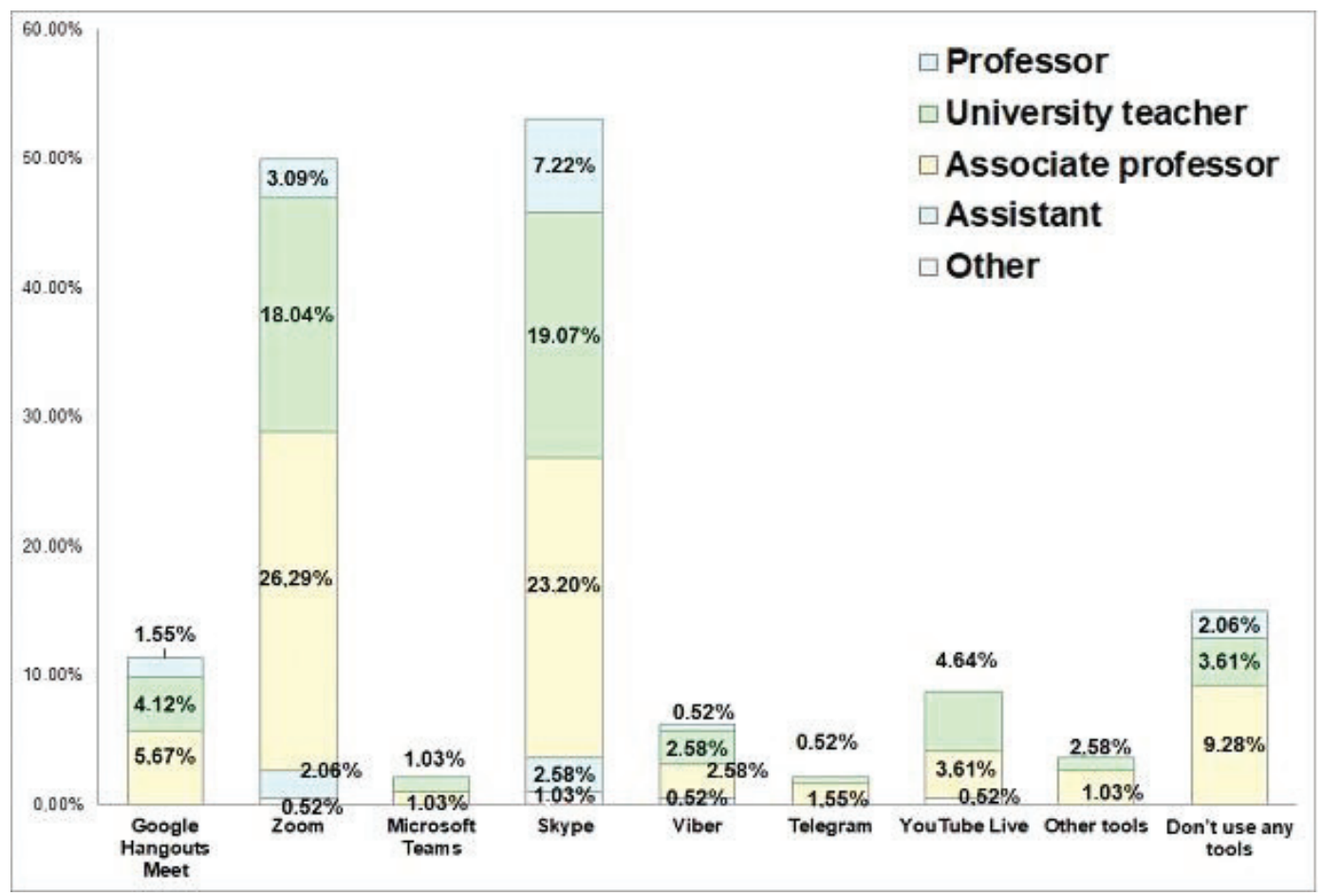

Figure 4. Survey responses on video conferencing tools' usage distributed by educational role

S ou rce: Own work

Q4: What tools do you use for designing and creating electronic teaching materials (tasks, exercises, practices, tests, etc.) in your professional activity?

Survey responses on using tools for designing and creating electronic teaching materials are shown in Fig. 5 (multiple answers are possible, which is why the total responses may be more than $100 \%$ ).

Fig. 5 shows that the most popular tools for designing and creating electronic teaching materials are Moodle (73.71\%), Google Forms (31.44\%) and H5P (29.38\%). In this case, materials developed using $H 5 P$ can be embedded in Moodle.

The group «other» includes the following tools: Quizizz, Testmoz, Socrative, Liveworksheets, Actionbound, Edpuzzle, Wordwall, Baamboozle, Classtime, Hot potatoes, Crosswordlabs, Easy generator, Idoceo, and Google Classroom. But their use is not very popular $(8,76 \%)$ among the tools used by the university teachers. This means that the teachers try to use Moodle (as a tool of education and within the informational environment of the university). At the same time, some respondents do not use any tools (about $8 \%$ ). 
Distance, Online and Blended Learning as Main Educational Trends...

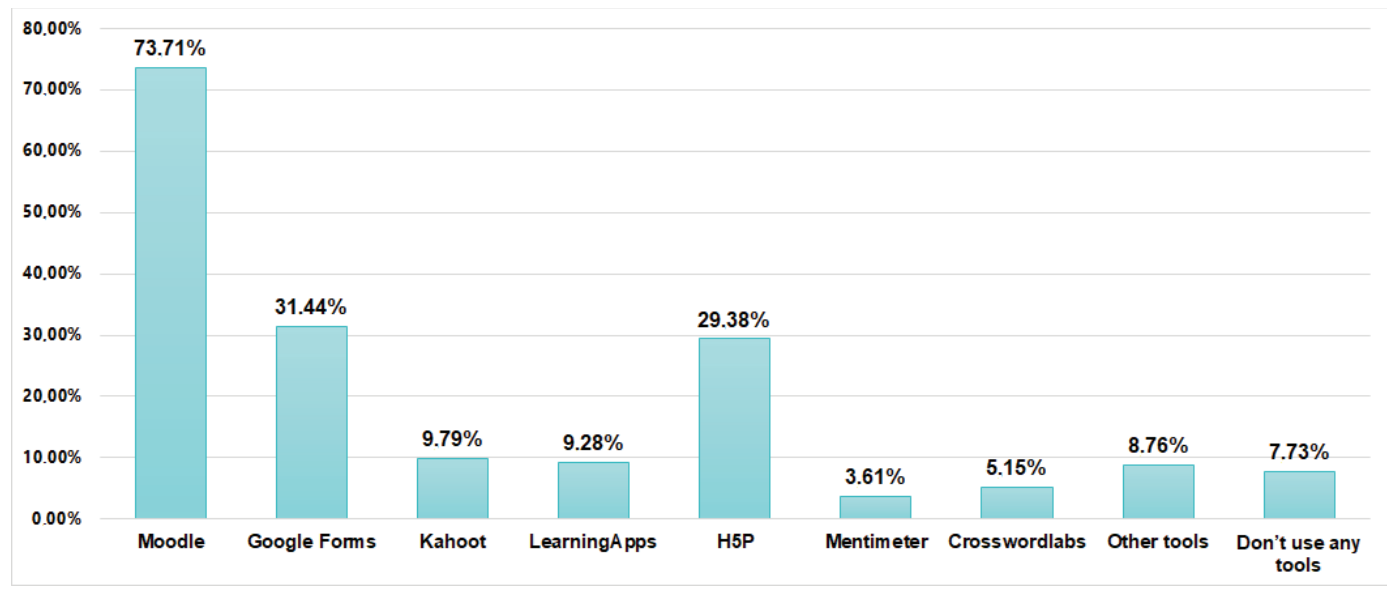

Figure 5. Survey responses on using tools for designing and creating electronic teaching materials

S ou rce: Own work

\subsection{The readiness of the Ukrainian university educators to improve their skills in using distance learning tools and online learning tools}

The data about the readiness of the Ukrainian educators from the target group to improve their skills in using distance learning tools and online learning tools is presented in Figs. 6-9 below.

Q5: What barriers/obstacles did you face during distance learning classes under the quarantine conditions?

Survey responses on existing barriers/obstacles during the conduction of distance learning classes under the quarantine conditions are shown in Fig. 6 (multiple answers are possible, which is why the total responses may be more than $100 \%)$.

The analysis of answers (given by educators from the target group) to questions about the obstacles to distance learning shows (Fig. 6) that most respondents (almost half of respondents $-48.97 \%$ ) have no experience in using distance learning tools and online learning tools. In addition, a significant proportion of respondents had limited technical capacity $(27.32 \%$ of respondents) to implement distance learning under the quarantine conditions due to the 2020 pandemic. At the same time, $22.16 \%$ of teachers believe that the management instructions concerning the organization of distance learning were not clear enough. $17.53 \%$ of respondents mentioned psychological problems regarding readiness to work under the conditions of distance and online learning. 
Oksana Strutynska, Mariia Umryk

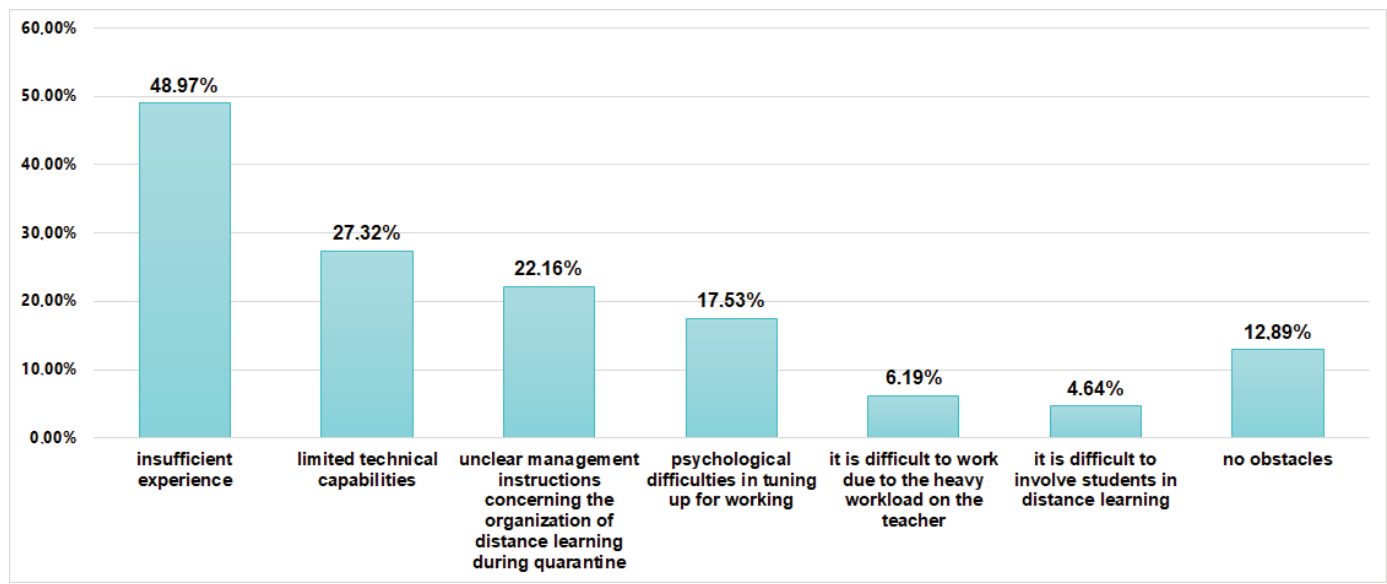

Figure 6. Survey responses on existing barriers/obstacles during distance learning classes under the quarantine conditions

S ou rce: Own work

The Digital Educational Technology Center was established at the Dragomanov National Pedagogical University to effectively organize the educational process under the conditions of distance, online and blended learning. Further actions of the Digital Educational Technology Center are aimed at solving these problems.

The idea that the workload of teachers under the conditions of distance and online learning is expanding (due to the need to develop qualitative electronic teaching materials, detailed instructions for organizing the learning process, different learning paths of students, checking and evaluating tasks, etc.) is also confirmed by the answers to the next question.

Q6: How much time (during the day) do you spend on preparing distance learning classes and online classes?

Survey responses on the preparation time (during the day) for distance classes and online classes are shown in Fig. 7.

Most of the interviewed teachers believe that their workload has increased significantly during distance and online learning. Fig. 8 shows that university teaching staff from the target group spend a lot of time every day to prepare for distance and online classes online (on average, at least 5 hours, taking into account pre-designed training courses for full-time study). 
Distance, Online and Blended Learning as Main Educational Trends...

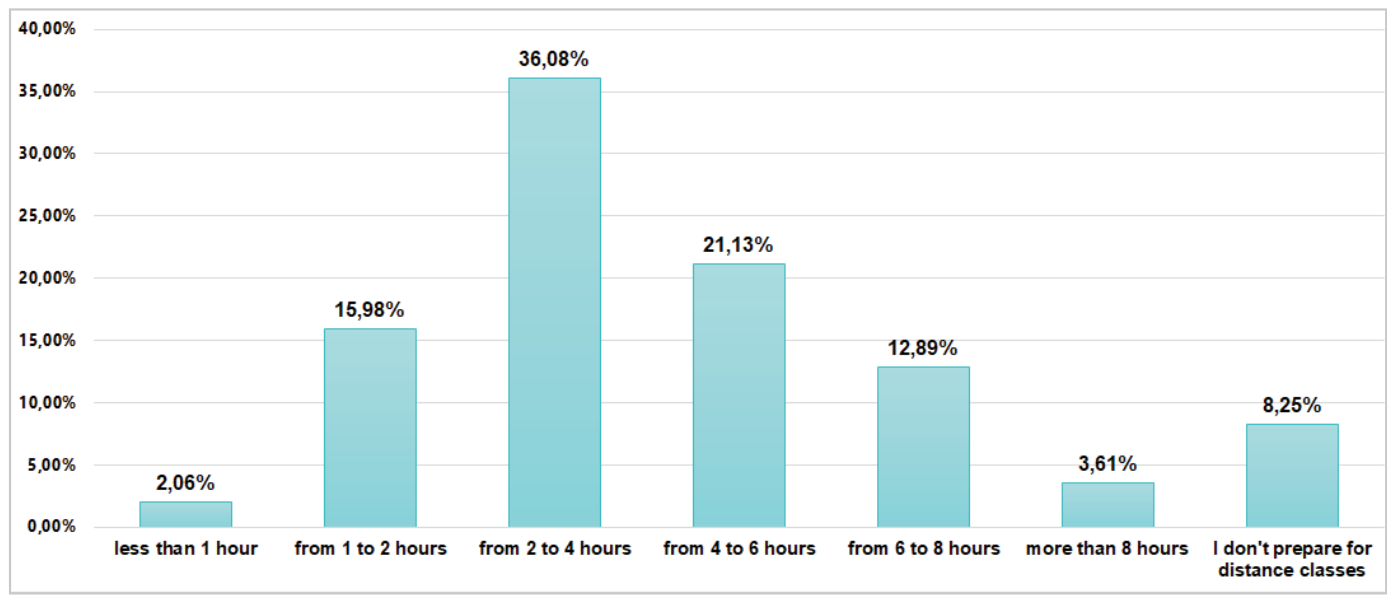

Figure 7. Survey responses on the preparation time (during the day) for distance classes and online classes

S o u r c e: Own work

Q7: Do you use MOOC platforms for self-education?

Survey responses on the use of MOOC platforms for self-education are shown in Fig. 8 (multiple answers are possible, which is why the total responses may exceed 100\%):

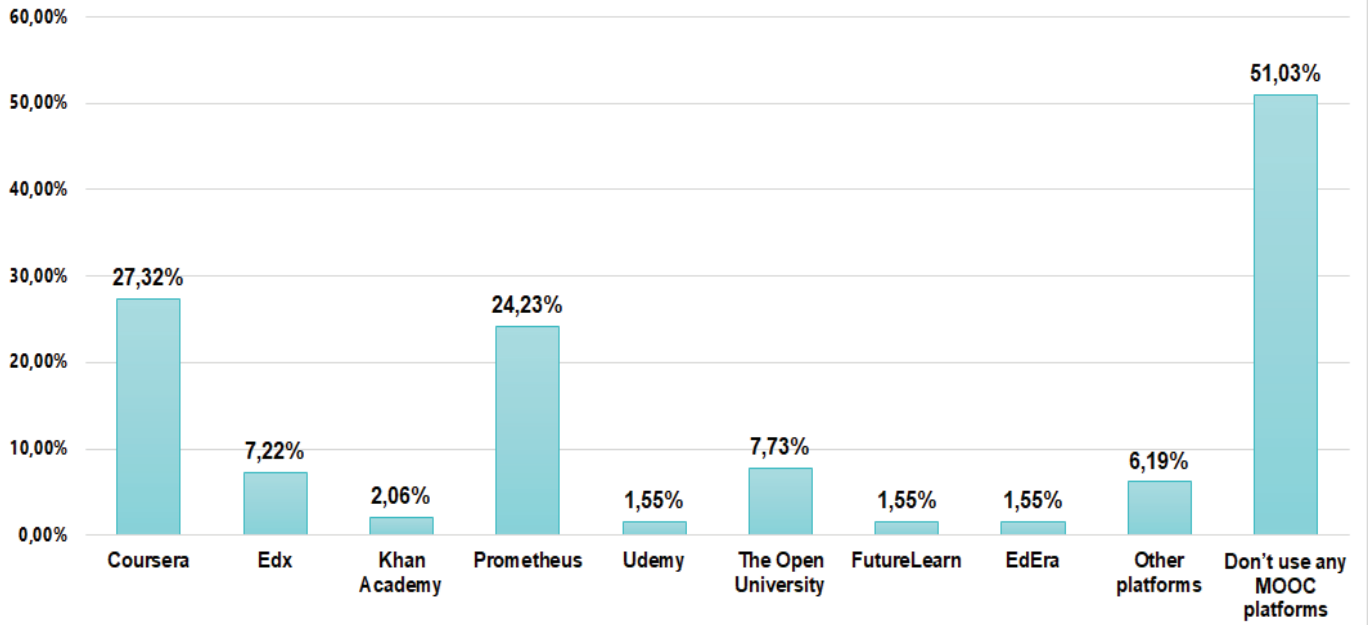

Figure 8. Survey responses on the use of MOOC platforms for self-education S ou rce: Own work 
As we can see from Fig. 8, the Ukrainian educators from the target group mostly use Prometheus (24.23\% responses) and Coursera for self-education (27.32\% responses). The reason for this fact is explained above. Another reason for using Coursera and $E d X$ by educators from the target group is the fact that the part of MOOC from these platforms was opened for University teaching staff and students (with the support of the Digital Educational Technology Center of the Dragomanov National Pedagogical University). Unfortunately, most of the respondents (51.03\%) do not use any MOOCs for self-education.

Q8: Would you agree to advanced training (retraining, second higher education, self-study) in order to implement distance and online learning technologies in the educational process?

Survey responses on the readiness of educators from the target group to advance training in the use of distance and online learning technologies in their own professional activity are shown in Fig. 9:

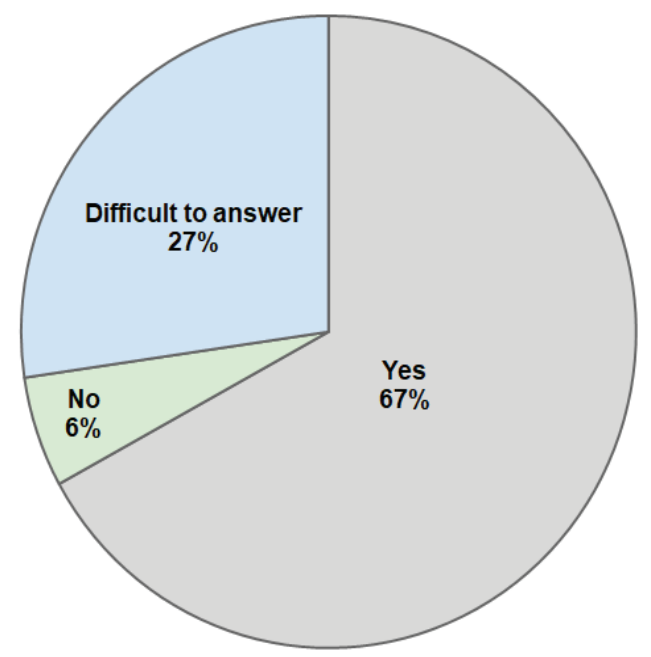

Figure 9. Survey responses on the readiness of educators from the target group to advance training in the use of distance and online learning technologies in their own professional activity

S ou r c e: Own work

As we can see from Fig. 9, most of the Ukrainian educators from the target group (67\% of the respondents) are ready to receive advanced training in the use of distance and online learning technologies in their own professional activity. We are planning to outline the ways to improve their Digital Competences in this field in our further research. 
Distance, Online and Blended Learning as Main Educational Trends...

\section{The Ways of Improving the Learning Process via Distance Learning Tools}

Modern educational institutions have faced new requirements even before the quarantine period (Morze, Smyrnova-Trybulska, \& Glazunova, 2017), (Kuzminska, Mazorchuk, Morze, \& Kobylin, 2019), (Kuzminska, Mazorchuk, Morze, \& Kobylin, 2020). On the one hand, according to the theory of generations, pupils and students have changed; on the other, the introduction of modern educational trends is one of the key conditions for the successful functioning of an educational institution. Some of the priority areas for educational institutions are (Strutynska \& Umryk, 2018), (Strutynska, Torbin, Umryk, \& Vernydub, 2020):

- digitalization and innovation;

- globalization (establishing an intercultural environment);

- mobility of students, pupils, teachers, and lecturers;

- distance and online learning;

- informal learning and MOOC technologies.

The conditions of the pandemic put the leaders of educational institutions up to reconsidering and changing approaches to the educational process. Accordingly, the digital environments of educational institutions were changed and adapted to form the digital analogue of physical institutions. Specialists with different success rates try to model the digital environment of all structural and learning components of educational institutions. Virtual classes, remote personal accounts, distance lectures, etc. have appeared. The problem of placement and full functioning of all the elements of the educational process in the distance and blended learning modes has also become extremely acute.

An example of such an adaptation is the following model of distance learning, which describes the features of the educational process' organization during the quarantine in the Dragomanov National Pedagogical University (Fig. 10).

This model of distance university work has arisen by force and, for the greater part, it was a quick response to the quarantine conditions in which the whole world found itself. In addition, the university management designed possible models of organization of the educational process in the Dragomanov National Pedagogical University in terms of full or partial distance learning:

1. Blended model.

2. Distance model.

3. Classical (face-to-face) post-quarantine learning model.

I. Blended learning model. The advantages of this learning model are recognized by many scholars and are widely used in universities. The model contains two components, such as distance and full-time (face-to-face) classical learning. The Dragomanov National Pedagogical University has implemented a blended learning model before the pandemic because this pedagogical technology could be very important for the formation of quality education. 


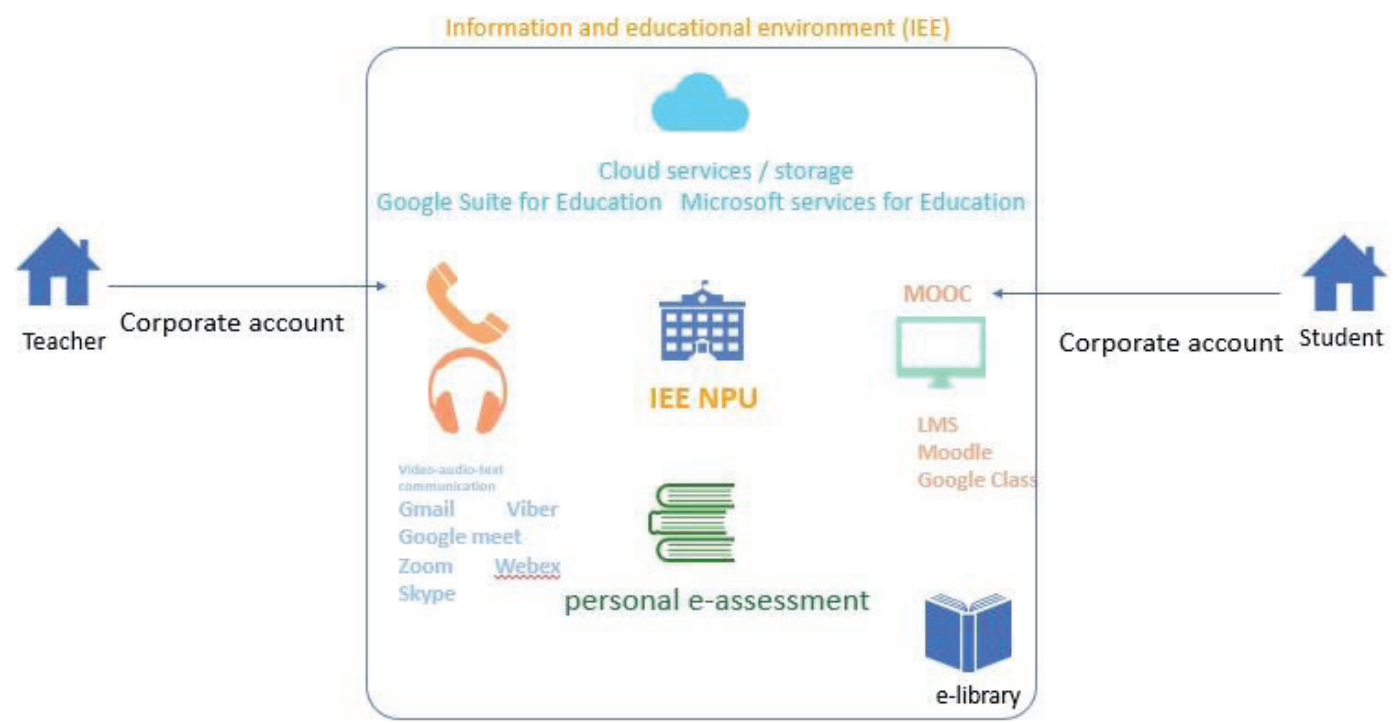

Figure 10. Educational process in the Dragomanov National Pedagogical University during the quarantine

S ou rce: Own work

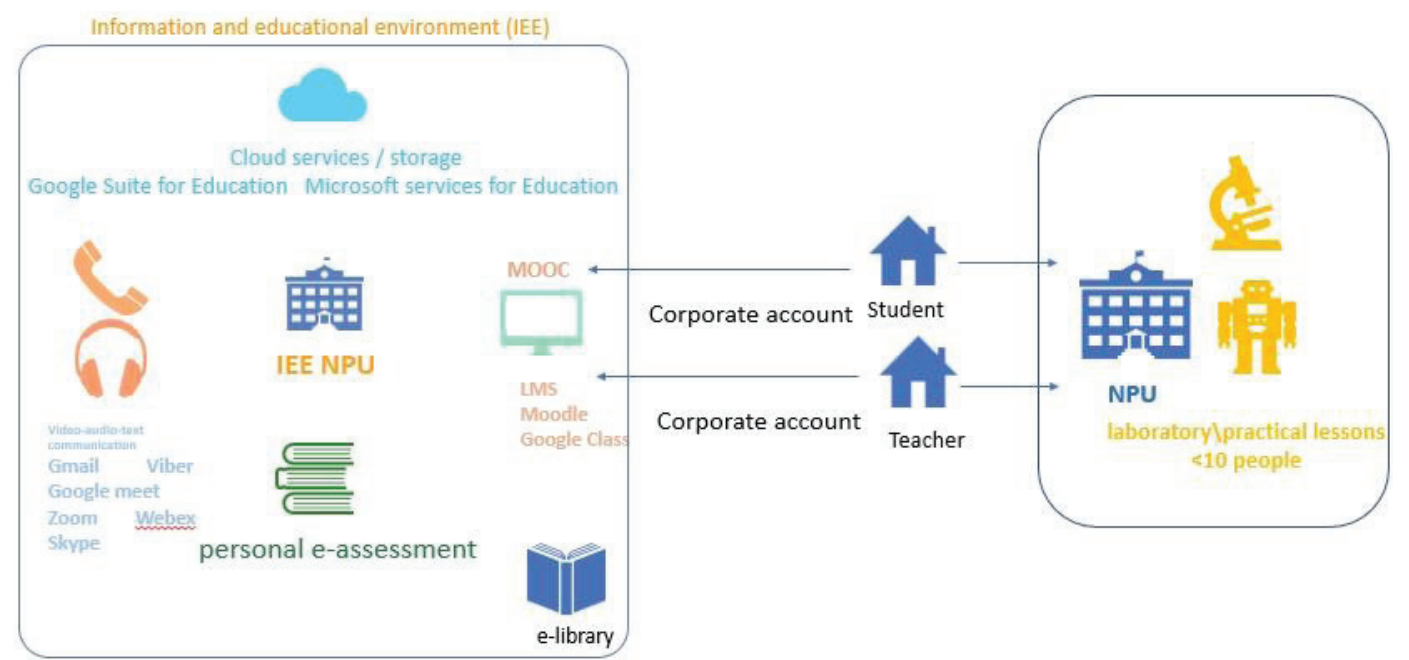

Figure 11. Blended learning model during the quarantine in the Dragomanov National Pedagogical University

S ou rce: Own work

Blended learning provides flexibility in relation to traditional learning. It also allows teachers to offer training in different variations of the presentation of 
Distance, Online and Blended Learning as Main Educational Trends...

educational material, containing the format of training courses, which is a harmonious combination of traditional and distance learning. Blended learning was implemented at the university as part of the use of the Moodle platform and elements of MOOC (massive open online courses) in full-time education. During the quarantine, the blended learning model was adapted and became more commonly used. The blended model is implemented through online classes with support for various distance learning technologies and through face-to-face classes in small groups of up to 10 people, taking into account the quarantine conditions (Fig. 11).

II. Distance learning model. The distance learning model was forced to be implemented during the quarantine. It includes solely online classes with support of various distance-learning technologies without the inclusion of face-to-face classes. This model is described above and shown in Fig. 10.

III. Classical model of face-to-face learning (post-quarantine). It is planned that all learning tools involved in and implemented during the quarantine should continue to work and improve the efficiency and quality of education. The postquarantine learning model includes traditional learning with distance support of all elements of the educational process (Fig. 12). Besides, there is a module of international activities of the university with international mobility for faculty and students.

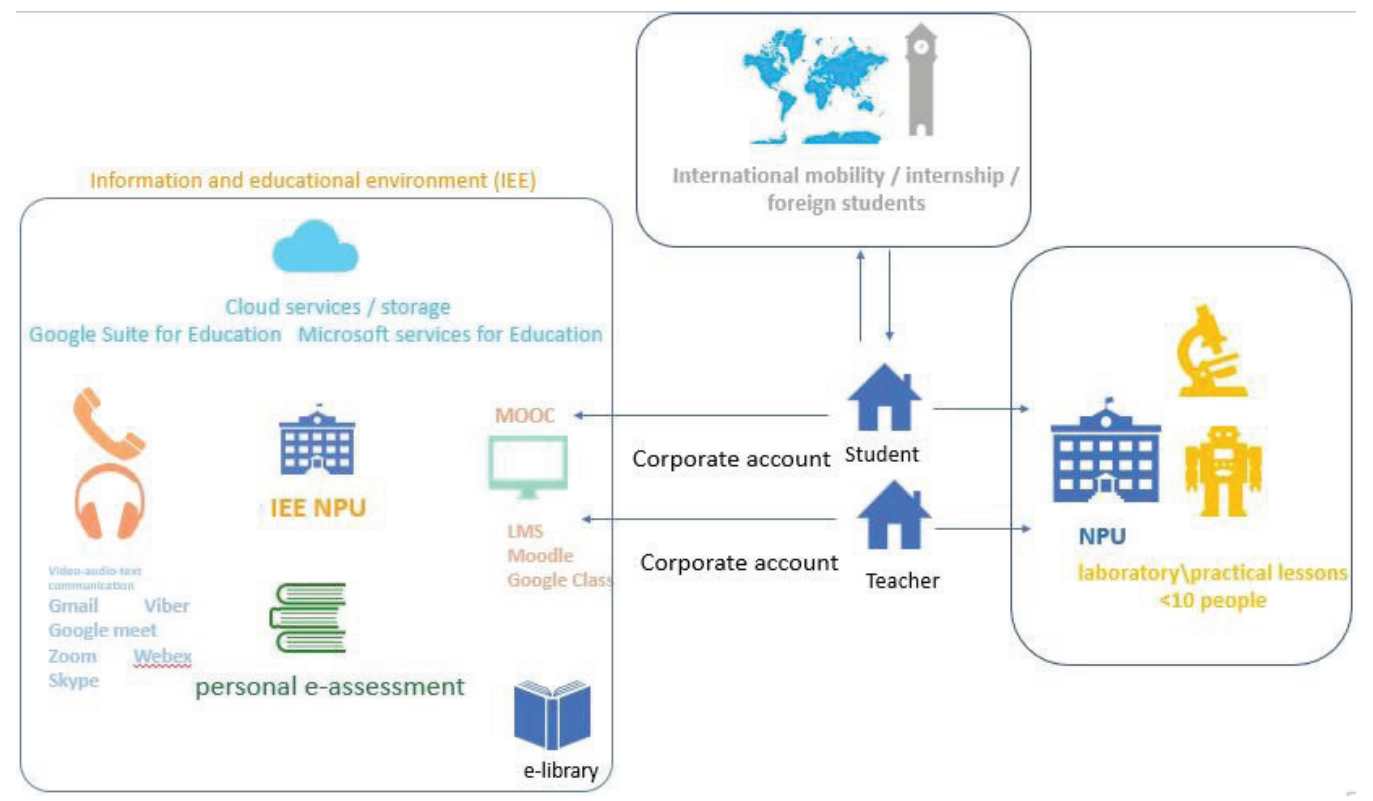

Figure 12. Classical (face-to-face) post-quarantine learning model in the Dragomanov National Pedagogical University

S ou r ce: Own work

IJREL.2021.7.1.02 p. 19/25 
Practical implementation of distance and blended learning models (that took place under the quarantine conditions due to the pandemic 2020) has shown their effectiveness. The survey results have shown the need to improve the skills of the Ukrainian educators from the target group in order to allow them to use the existing information and education environment of the Dragomanov National Pedagogical University effectively and ensure a high-quality educational process. It is obvious that the classical post-quarantine learning model will be specified by an increase in the share of distance learning tools and online learning tools in general.

\section{Discussion}

The survey results show that the level of knowledge and skills of the target group as regards the use of distance learning tools need to be improved. The possibilities of development should take the following issues under consideration:

1. Survey responses on video conferencing tools' usage have shown that about $15 \%$ of educators from the target group did not use any tools. Also, more than half of the respondents use Zoom and Skype without verification and authentication (Fig. 4).

It means that there is a need to improve their skills in the use of distance learning tools and online learning tools, i.e., video conferencing tools. The paths to development are provided through the training and retraining of future teachers.

2. Survey responses on the use of tools for designing and creating electronic teaching materials (Fig. 5) indicate a lack of technical means for the development of electronic teaching materials and/or the need to improve skills in the development of relevant digital competencies. The last issue needs further research.

3. Survey responses on existing barriers/obstacles during distance learning classes under the quarantine conditions have shown that university teachers need psychological support, which can be organized in the form of training conducted by psychologists who deal with similar problems (Fig. 6). The Faculty of Psychology of the Dragomanov National Pedagogical University provides special training for educators.

4. Survey responses on using MOOC platforms for self-education have shown that the university must implement a motivation system (a system of incentives) in order to change this situation (Fig. 8). One of the possible solutions is considering certified MOOCs as advanced training of teaching staff. 
Distance, Online and Blended Learning as Main Educational Trends...

Recommendations:

- Retraining of the University teaching staff to improve their skills in the use of distance learning tools and online learning tools have started in the current academic year (2020-2021), supported by the Digital Educational Technology Center of the Dragomanov National Pedagogical University.

- The involvement of university teacher staff in the psychological training to support them under quarantine conditions.

- Proposed models need to be improved to account for the rapid development of digital technologies and the appearance of new learning tools.

\section{Acknowledgements}

The present research was organized and supported by the Digital Educational Technology Center of the Dragomanov National Pedagogical University.

\section{Conclusions}

Under the conditions of the 2020 pandemic, such models of study as distance, online and blended learning now are educational trends. The task of every educator is to be skilled in using distance, online and blended learning tools for the effectiveness of professional activity. Therefore, the analysis of the educators' level of skills and awareness in this matter is the starting point for decisive changes in improving the competence of educators and organizing the educational process in general.

The authors also propose to improve the teaching-learning process in the field of digital competencies' development through the training of future teachers in the Dragomanov National Pedagogical University to prevent the gaps in their future professional activity.

Based on the experience gained in this research and on the feedback received from the target group, the authors are planning a scenario for the next steps in improving the Ukrainian educator's level of knowledge and skills in the use of distance learning tools and trends in their professional activity, especially under quarantine conditions: 
- the analysis and adaptation of the best European practices in the use of the distance learning tools in the professional activity for the training of Ukrainian educators;

- design of the curriculum for the retraining of Ukrainian educators and implementing it in the Dragomanov National Pedagogical University for the development of Educators' Digital Competences in using distance, online and blended learning tools;

- update of the informational and educational environment for improving the teaching-learning process of the Dragomanov National Pedagogical University;

- design of the possible models of the teaching-learning process of the Dragomanov National Pedagogical University (supported by the Digital Educational Technology Center) under the quarantine.

\section{References}

Allen, I. E., \& Seaman, J. (2011). Going the Distance: Online Education in the U.S. Babson Survey Research Group and Quahog Research Group.

Blended learning: essence and advantages in the modern world. (2019, May 24). Retrieved from EdEra: http://blog.ed-era.com/blended-learning-sut-pierievaghi-ta-uspishni-prikladi

Buhaichuk, K. L. (2016). Blended learning: Theoretical Analysis and Strategy of Implementation in Educational Process of Higher Educational Institutions. Information Technologies and Learning Tools, 54(4), 1-18. doi: https://doi.org/10.33407/itlt.v54i4.1434

Clayton Christensen Institute for Disruptive Innovation. Blended Learning. (n.d.). Retrieved from Clayton Christensen Institute for Disruptive Innovation: http://www.christenseninstitute.org/ key-concepts/blended-learning

Digital 2020: Ukraine - DataReportal - Global Digital Insights. (2020, February 18). Retrieved from DataReportal: https://datareportal.com/reports/digital-2020-ukraine

Economic Strategy of Ukraine 2030. Ukrainian Institute of the Future. (n.d.). Retrieved from Ukrainian Institute of the Future: https://strategy.uifuture.org/index.html

Education: From disruption to recovery. UNESCO. (2020). Retrieved from UNESCO: https:// en.unesco.org/covid19/educationresponse

Hrynevych, L. (2020, April 28). Education after the pandemic. Part 2. Trends in the future of school education. NUS. Retrieved from NUS: https://nus.org.ua/view/osvita-pislya-pandemiyichastyna-2-trendy-majbutnogo-shkilnoyi-osvity

Huawei Predicts 10 Megatrends for 2025. (n.d.). Retrieved from Huawei: https://www.huawei.com/ en/news/2019/8/huawei-predicts-10-megatrends-2025

Kemp, S. (2020). «Digital 2020 Ukraine». Hootsuite \& We Are Social, retrieved from DataReportal: HYPERLINK "https://datareportal.com/reports/digital-2020-ukraine" https://datareportal. com/reports/digital-2020-ukraine

Kuzminska, O., Mazorchuk, M., Morze, N., \& Kobylin, O. (2019). 15th International Conference on ICT in Education, Research and Industrial Applications. Integration, Harmonization and 
Distance, Online and Blended Learning as Main Educational Trends...

Knowledge Transfer (ICTERI 2019). Attitude to the digital learning environment in Ukrainian Universities. Vol. 2393 (pp. 53-67). Kherson: CEUR Workshop Proceedings. Retrieved from http://ceur-ws.org/Vol-2393/paper_245.pdf

Kuzminska, O., Mazorchuk, M., Morze, N., \& Kobylin, O. (2020). Communications in Computer and Information Science. Digital Learning Environment of Ukrainian Universities: The Main Components to Influence the Competence of Students and Teachers, 210-230. 1175 CCIS.

Morze, N. V., Kucherovska, V. O., \& Smyrnova-Trybulska, E. N. (2020). Self-Estimation of an Educational Institution's Digitalization Level Under the Conditions of Secondary Education Transformation. Open educational e-environment of modern University 8, 72-87. doi:https:// doi.org/10.28925/2414-0325.2020.8.8

Morze, N. V., Smyrnova-Trybulska, E. N., \& Glazunova, O. G. (2017). Design of a university learning environment for SMART education. In Smart Technology Applications in Business Environments (pp. 221-248).

Morze, N. V., Vember, V. P., \& Hladun, M. A. (2019). 3 d mapping of digital competency in ukrainian education system. Information Technologies and Learning Tools, 70(2), 28-42. doi: https:// doi.org/10.33407/itlt.v70i2.2994

NMC Horizon Report Preview. (2018). Retrieved from Educause: https://bluesyemre.files.wordpress. com/2018/08/previewhr2018.pdf

Project «Digital agenda of Ukraine 2020». (2016, December). Retrieved from https://ucci.org.ua/ uploads/files/58e78ee3c3922.pdfRashevska, N. V. (2010). Blended learning as a psychological and pedagogical problem. Bulletin of Cherkasy University. «Pedagogical sciences». 191, 89-96.

Sánchez Begines, J., Escalona, M., Strutynska, O., Umryk, M., Wojdynsky, T., \& Dominguez-Mayo, F. (2017). Information Systems Development: Advances in Methods, Tools and Management (ISD2017 Proceedings). The Importance of User in ISD. Do We Really Teach? Larnaca (Cyprus): University of Central Lancashire Cyprus. Retrieved from http:/aisel.aisnet.org/isd2014/ proceedings2017/Education/5

Strutynska, O., \& Umryk, M. (2018). Analysis of Development Level of the Digital Competences of the Ukrainian Educators. In E. Smyrnova-Trybulska (Ed.), E-learning and Smart Learning Environment for the Preparation of New Generation Specialists (Vol. 10, pp. 615-639). Katowice-Cieszyn (Poland): Studio Noa for University of Silesia. Retrieved from http://weinoe. old.us.edu.pl/sites/weinoe.us.edu.pl/files/media/10-615.pdf

Strutynska, O., Torbin, G., Umryk, M., \& Vernydub, R. (2020). 8th Workshop on Cloud Technologies in Education (CTE 2020). Digitalization of the educational process for the training of the future teachers. Kryvyi Rih (Ukraine).

Oksana Strutynska, Mariia Umryk

\title{
Nauczanie na odległość, online i mieszane jako główne trendy edukacyjne w warunkach pandemii 2020
}

\author{
Streszczenie
}

Tendencja do uczenia się na odległość i samokształcenia nie zmieniła się od wielu lat, ale podczas pandemii stała się niezwykle istotna i ważna. Zamknięcie szkół i instytucji szkolnictwa wyż-

IJREL.2021.7.1.02 p. 23/25 
szego na całym świecie miało negatywny wpływ na sektor edukacji w wielu krajach i dotknęło prawie każdego studenta i nauczyciela. W artykule przeanalizowano poziom wiedzy i umiejętności ukraińskich edukatorów w zakresie korzystania z nowoczesnych narzędzi i trendów w nauczaniu na odległość oraz sposób doskonalenia procesu nauczania-uczenia się w warunkach pandemii 2020. Autorzy przedstawiają przegląd trendów edukacyjnych w warunkach nauczania na odległość, online i blended learning. Zbadano również poziom wiedzy i umiejętności ukraińskich nauczycieli dotyczący korzystania z nowoczesnych narzędzi i trendów w nauczaniu na odległość. W tym celu autorzy opracowali i wdrożyli lokalną ankietę dla kadry dydaktycznej ukraińskiego uniwersytetu (grupa docelowa), która musi korzystać z narzędzi uczenia się na odległość w swoich badaniach i działalności zawodowej podczas kwarantanny. Autorzy przedstawiają również sposoby usprawnienia procesu uczenia się za pomocą narzędzi nauczania na odległość.

S łow a kluc z ow e: narzędzia uczenia się na odległość, trendy uczenia się na odległość, COVID-19, transformacja cyfrowa, narzędzia edukacyjne, trendy edukacyjne

Оксана Струтинская, Мария Умрык

\section{Дистанционное, онлайн и смешанное обучение как основные образовательные тренды в условиях пандемии 2020}

Анно т а ция

Тенденции последних лет показывают актуальность дистанционного обучения и самообразования, но во время пандемии они стали критически важными. Закрытие школ и высших учебных заведений по всему миру оказало негативное влияние на сектор образования во многих странах в целом и затронуло почти каждого учащегося и преподавателя. В данной статье исследуется уровень знаний и навыков украинских педагогов в контексте умений использования ими современных инструментов дистанционного обучения. Рассмотрены возможности улучшения учебно-педагогического процесса в условиях пандемии 2020 года. Авторы приводят обзор образовательных тенденций в условиях дистанционного, онлайн и смешанного обучения. Также исследуется уровень знаний и навыков украинских педагогов в использовании современных инструментов дистанционного обучения. С этой целью авторы разработали и провели опрос украинских преподавателей педагогического университета (из целевой группы), которым необходимо использовать инструменты дистанционного обучения в своей исследовательской и профессиональной деятельности во время карантина. Авторы также рассматривают способы улучшения процесса обучения с помощью средств дистанционного обучения.

К л юче в ы е с ло в а: инструменты дистанционного обучения, тренды дистанционного обучения, COVID-19, цифровая трансформация, инструменты для обучения, образовательные тренды

IJREL.2021.7.1.02 p. 24/25 
Distance, Online and Blended Learning as Main Educational Trends...

Oksana Strutynska, Mariia Umryk

\title{
El aprendizaje a distancia, en línea y mixto como principales tendencias educativas durante las condiciones de la pandemia de 2020
}

\begin{abstract}
Resumen
La tendencia hacia el aprendizaje a distancia y la autoeducación no ha cambiado durante muchos años, pero durante la pandemia, adquirió una relevancia e importancia fundamentales. El cierre de escuelas e instituciones de educación superior en todo el mundo tuvo un impacto negativo en el sector educativo en muchos países en general y ha afectado a casi todos los estudiantes y educadores. Este documento examinó el nivel de conocimientos y habilidades de un grupo seleccionado de educadores ucranianos en el uso de herramientas y tendencias modernas de aprendizaje a distancia y la forma de mejorar el proceso de enseñanza-aprendizaje durante las condiciones de la pandemia de 2020. Los autores presentan su revisión de las tendencias educativas en las condiciones de aprendizaje a distancia, en línea y mixto. También examinó el nivel de conocimientos y habilidades de los educadores ucranianos en el uso de herramientas y tendencias modernas de aprendizaje a distancia. Para ello, los autores han elaborado e implementado una encuesta local del personal docente universitario ucraniano (grupo objetivo) que necesitan utilizar herramientas de aprendizaje a distancia en su investigación y actividad profesional durante la cuarentena de 2020 . Los autores también presentan formas de mejorar el proceso de aprendizaje a través de herramientas de aprendizaje a distancia.
\end{abstract}

Palabras clave: Herramientas de aprendizaje a distancia, Tendencias de aprendizaje a distancia, COVID-19, Transformación digital, Herramientas de aprendizaje, Tendencias educativas 